\author{
PRE-PRESS VERSION \\ FULL VERSION AVAILABLE HERE: \\ http://dx.doi.org/10.1108/S0190-1281(2010)0000030012
}

\title{
HOSTILE WORLDS AND QUESTIONABLE SPECULATION: RECOGNIZING THE PLURALITY OF VIEWS ABOUT ART AND THE MARKET
}

\author{
Erica Coslor \\ Department of Sociology, University of Chicago, Chicago IL, USA
}

\begin{abstract}
The "hostile worlds" view argues that money corrupts the meaning of art, but some suggest this is a dated concept in describing the art market. Instead of dismissing this view, this paper argues that we need a typology of beliefs about art, money and commensuration; what could be understood as a pluralist understanding. Based on ethnographic research on the high-end contemporary art market in New York and London, I find that collectors, investors and art world experts often have different views about the relationship between art and money. This recognition is significant because art is a symbolic good with assigned, rather than intrinsic value, meaning that the value of art can be damaged for people holding hostile worlds views when the mechanisms that maintain the appropriate balance between art and money break down or are disregarded. In this sense, hostile worlds views create a performativity effect.
\end{abstract}

\section{Keywords:}

Art market, commensuration, commodification, hostile worlds view, performativity

(Last revised 10-10-09) 


\section{INTRODUCTION}

In his BBC documentary, The Mona Lisa Curse (Chang, 2008), noted art critic Robert Hughes argued that "when art is so closely tied to the market, something is lost." In this chapter, I examine several perspectives about the appropriate connections between art and the market. Hughes' viewpoint illustrates one extreme: the idea of hostile worlds, where the mixing of art and money is considered damaging. This view, as well as my own approach, draw from the "contested commodity" framework (Radin, 1996) for goods that interact problematically with the market, such as the market for body parts (Healy, 2006) and babies (Zelizer, 1985). ${ }^{1}$ At the other extreme we could put an economic view, where art becomes a commodity like others, to be examined through the impersonal influences of supply and demand.

These two extremes become part of a theory that the economy and culture inhabit two separate spheres, that may be independent or may come together and contaminate one another, as independent spheres or a contamination model, respectively (e.g. Velthuis, 2003; Zelizer, 2006, p. 305). If economy and culture were "two unrelated spheres," the separation would prevent the market from influencing the aesthetic or cultural valuation of art, and this can be seen in unproblematic economic models for artwork. However, the hostile worlds theory suggests a contamination model, where the two spheres collide, and prices can contaminate the cultural value of artwork in various ways, turning it into a homogeneous commodity (Velthuis, 2003, p. 183). ${ }^{2}$

Based on these two extremes, and findings from my ethnographic research on the high end art market in New York and London, I argue that we must have a pluralist understanding of beliefs about the relationship between art and money, as opposed to 
imagining that one or another of these views is correct. I believe that a pluralist understanding is particularly helpful in the case of artwork, because art is a symbolic good with assigned, socially constructed value, rather than intrinsic value. This means that the value of art can be damaged for people holding contested commodity or hostile worlds views if the mechanisms that maintain the appropriate balance between art and money break down or are disregarded. As I will show, these views are often present in artists, critics and even collectors. At the same time, art sales are a place where the worlds of money and cultural meaning come together with regularity, requiring work to maintain the boundaries of acceptable practice in order to appease those who hold hostile worlds views. This process of selling art in ways that do not diminish its value can be understood as similar to the regular work we do in when inserting money into intimate relationships. When buying gifts for children, buying engagement rings, and so forth, we take care to mix money and relationships in a way that will not signify the wrong type of relationship, in what Viviana Zelizer calls "good matches" (Zelizer, 2000, 2006).

These concerns with the appropriate relationship between art and money are being stirred up anew by more recent interest in speculative investment in artwork. This speculative interest has always been present in some form, such as the Peau de l'ours (skin of the bear) investment scheme in Paris in 1904 (Green, 2003, p. 54), but art investment has become a topic in the last few years in the financial investment community. ${ }^{3}$ A steady stream of articles in financial publications like the Wall Street Journal and The Financial Times indicates the growing interest in art investment. One driving factor for this activity is the trend of 'superprices' for art (Koenigsberg, 1989), illustrated in the sale of Richard Prince’s 'Surfing Nurse' for over £2.1 million $(\$ 4.2$ 
million) in 2003 (Haden-Guest, 2008), and despite recent price drops due to the 2008 financial crisis, interest is expected to continue. Along with high prices, justification for investing in artwork comes from an interest in financial portfolio diversification, and the finding by some cultural economists that artwork is less correlated to other types of financial investments (Campbell, 2008). Drawing again on the idea of "good matches" we can see some tensions and resolutions in this area as well.

\section{RESEARCHING THE HIGH-END INTERNATIONAL ART MARKET}

This article is based upon a three year ethnographic project on the use of art as an investment and financialization of the art market. I focused primarily on contemporary art, because it is an area where the arguments about art and money are sharper because the careers of living artists are intertwined with market practices, but in the course of the research, I talked to people associated with various artistic periods. The research included 13 months of primary fieldwork in New York and London, from January 2008 to February 2009, with additional event-based ethnography before and after this time. These cities were chosen because they are top cities for art sales and institutions (Carrier, 2003; Watson, 1992) as well as financial centers (Sassen, 2001; Taylor, 2000). I used a multisited ethnography approach (Marcus, 1995) in an attempt to 'follow the object' of art investment through different channels.

I began the early field research with event-based observation at auctions in Chicago in 2006, which gave me familiarity with the auction process, and then moved to look at auctions in New York and London, particularly at Sotheby's, Christie's and Phillips de Pury. International art fairs and public lectures put together by the Art Dealer's Association of America in New York were additional opportunities for 
participant observation, as well as solicitation of some of my interviewees; in total, I attended 29 events including the nine initial Chicago auctions. My 32 interviews included members of the art world and art investment community, included an art fund representative, a museum director, an art consultant, artists, gallerists and others. ${ }^{4}$ Excellent secondary data came from a review of 22 Master's dissertations on art investment at the Sotheby's Institute of Art in London, where outside researchers are allowed to review student work on-site. ${ }^{5}$ The background research includes academic reading, as well as research from The Art Newspaper, Art+Auction, and the New York Times arts section. This event-based strategy was partly opportunistic and partly due to the mobile nature of the art market, where auctions and fairs are key meeting points. Although it is difficult to estimate the size of the fine art market, due to the tendency by dealers to keep prices private, the U.S. and European art markets were estimated at some $\$ 20$ billion in 1999 (Robertson, 2005, p. 30). The global art market is also Western-dominated, with the U.S. and U.K. markets comprising approximately $70 \%$ of the world market in terms of weighted value (Goodwin, 2008, p. 1). While Paris used to be a major sales center for artwork, today New York and London compete for the top position in art sales (Watson, 1992), and Sotheby's and Christie's auction houses are headquartered in New York and London, respectively.

My research on the high end art market goes along with current trend in anthropology to study elite cultures (Shore \& Nugent, 2002), high technology, and Western sites of study, such as financial options traders (Zaloom, 2006) and Wall Street (Ho, 2009). My decision to focus on the people, institutions and processes that occur at the highest levels of this market was partly functional, because high end, "blue chip," art 
is typically the area of focus for art investors. But this high end art market is also significant because what happens there has a cascade effect, and often shapes practices at other levels. This area of study has also presented some challenges, because as with many studies of high prestige subjects (See Odendahl \& Shaw, 2002), access was at the discretion of the interviewee and I faced many instances where people declined to speak with me. However, as a young, white, American woman — and particularly after I learned to dress the part—I appeared to belong in the same category as art history students and other young practitioners in the art world. This seemed to put my interviewees at ease, for the most part, and they seemed to readily answer my questions. However, I quickly found that in describing my project, the mention of art and money or art as an investment could elicit hostility or other negative responses. In order to really talk with people in this world about art, money and investment, I had to reframe my questions in a more careful fashion. This paper is based on some of these interactions.

Before going into the topic of art and money, it would be useful to describe one of my common research settings, the high end art fair. A typical example was the London Art Fair, held in the Business Design Centre, in London's Islington neighborhood in January 2009. The building was a small convention center design, with permanent office spaces along the outer walls and many temporary gallery spaces set up inside. These gallery spaces are made of white-painted plywood, and vary in size. Gallery assistants hang paintings according to directions, and while some booths are quite cluttered with artwork, others have a minimalist design. Paintings are also the predominant form of media, although there are a few dealers with sculptures, fiber art, dioramas and other forms. Bright little spotlights illuminate the work and make the building quite warm after 
a few hours. Most art fairs have a limited preview session, usually held on the day or evening before the event opens to the public. Tickets to this event command a premium, but free passes are distributed to the galleries to provide to their main collectors, in addition to press passes given to journalists and critics of various persuasions. According to some, the preview sale of a fair is when the real sales are conducted, while the rest is essentially a public exhibition, but I did witness gallerists selling work to people on other days. After the fair opens, people begin to fill the hallways created by the exhibition booths, and they are a mixture of potential buyers, artists and art lovers, students, and the general public. ${ }^{6}$ Such a diverse crowd is an excellent way to witness various views about the appropriate connections between art and money.

\section{HOSTILE WORLDS BETWEEN MONEY AND ART}

In the hostile worlds view there is a split between a sacred area of cultural value and the profane world of money and prices, a split between culture and economy (Reviewed in Velthuis, 2003, 2005; Zelizer, 2000). Because the market and money are seen to exert a corrupting influence on the value of aesthetic goods, it is attractive for those who hold this view to suggest that creative production should be kept separate from the market, because the cultural value of artwork can be "trivialized by pricing it" (Velthuis, 2003, p. 183). This is based on a certain legacy of Romantic sentiments (See Wolff, 1981), or ideas about the transcendental nature of artwork. ${ }^{7}$ These were sincere and relevant concerns for many of the art collectors and others in the art world, but I was surprised to find this was less of a concern than I had imagined for those in professional roles-artists, gallery directors, curators - people who deal with art market and the relationship between art and money in their everyday work. This is in part because commodification and 
commensuration concerns have been discussed and problematized in the professional art world in earnest since the 1970s, which is not to say that these concerns have evaporated, but as one art historian told me, an 'art vs. money' or hostile worlds critique is considered simplistic and outdated. ${ }^{8}$

When actually speaking with people involved in the art market, I ran into certain variations of hostile worlds concerns quite often. Although not everyone who holds this view would label themselves as such, it became an easy shorthand to characterize some commonly held views about art and money, and the comments by critic Robert Hughes at the beginning of this piece are only one example. ${ }^{9}$ Another common response was to disparage the motives of those who bought artwork for investment purposes, as seen in this comment by art professor and critic Elaine King: "There are two kinds of collectors. One type buys work because they love the work," and the other wants the money or other benefits of collecting. ${ }^{10}$ In King's view, an emotional connection to the artwork is more pure or valorous than the instrumental goals of monetary gain or social status. As opposed to the purist ideas about artwork, a more elitist critique was that speculation in art and the interest in prices was vulgar; ${ }^{11}$ although money went along with the artwork, a focus on money showed lack of refinement.

While people who hold hostile worlds views imagine a problematic relationship between art and the market, there are also individuals who saw no problem with the mixing of art and money, or what could be called the independent spheres view (Velthuis, 2003). For example, the cultural economics view of art paints it as a commodity that provides satisfaction in the form of utility, and aesthetic value is transformed into economic value (Chong, 2005, p. 89). I often noticed this unproblematic mixing of art 
and money when speaking with economists about my work, and usually had to explain that there were some people who saw problems with the excessive commodification of artwork, even if the economists did not.

Returning to the hostile worlds viewpoint, we can also tease out some related commensuration concerns, due to questions of what it means to turn art into money and vice versa (n.b. Shell, 1995). Velthuis argues that art historians and cultural experts in particular subscribe to the hostile worlds view by "insisting on the incommensurability of art" (2003, p. 187). Commensuration, or the process of making art equal with a sum of money, is seen as problematic mainly because of the association with an impure market or some variation on this theme, but it has a number of other dimensions, such as making things comparable that should not be considered comparable (n.b. Espeland, 2002; Espeland \& Stevens, 1998).

Although the idea of exchanging money for art is the standard way to think about this market, it is possible to commensurate art with things other than money, and for some who hold hostile worlds views, this may even have been preferable. For example, in reaction to high auction prices in the last art bubble, art historian M. D. Edwards wrote that he discourages students from thinking about the monetary value, suggesting instead that they think of the 'infinite emotional value' or alternatively, the cost of time and materials (1991, pp. 12-13). These suggestions speak to the question of what art is traded for, with non-monetary or trivial money trades as more morally acceptable (to Edwards) than high monetary value. Although not explicitly developed by Edwards, I read this as a concern that the perceived worth of artwork stems from its high price, rather than the worth being in the cultural dimensions of the work, which then may justify a high price, 
due to its significance. This would lead us to a different solution than a market price being set by the interaction of supply and demand; it represents an ideal of how prices should be constructed, as seen from a hostile worlds or commensuration concern perspective.

A final commensuration concern is that of homogenization, which occurs as goods are made comparable through a system of fungible prices, as well as through the process of categorization. Whether it is conducted through a system of prices or otherwise, this homogenization and 'making same' of different artist and artworks may be morally opposed. An overly general abstraction can also seem nonsensical due to the variations among different type of art, as I found when doing a presentation to the Chicago Workshop on Contemporary Art. The artists and art historians who attended were bemused by the category "All Art" of an art price index that I displayed. The idea of "All Art" was laughable because it mixed together too many disparate types of work.

Aside from these commodification concerns, in my interviews, I found that even among people who did not subscribe strongly to the hostile worlds view there was a concern that in today's art market that the monetary values have overwhelmed the nonmonetary values. One reason, as some critics argue, is that both the media and new collectors confuse money and value; the media tends to equate fame with artistic innovation and many new collectors end up "buying the price," when they confuse monetary value with aesthetic and cultural value (Thornton, 2008). Robert Hughes himself wrote a critical piece on artist Damien Hirst, suggesting that Hirst's auction prices were disproportionate to his talent (Hughes, 2008), which reiterates the idea that in 
a hostile worlds view there should be an orderly relationship between prices and artistic merit.

\section{COMMENSURATION 2: TRADING ART, STOCKS AND PORK BELLIES}

Similar to concerns about how art is exchanged for money, art investment elicits another type of contested commodity concern, in part because the price and high monetary value is seen to overwhelm the cultural value, but also for the association with gambling. For example, in 1973, Lord Clark complained about art investment: "I hate the whole idea of art being turned into a kind of stock exchange or gambling parlor... I hate the whole idea of art becoming a form of stock exchange investment. It's a ruinous, wicked, degrading thing" (quoted in Steiner, 2001, p. 213). This concern again put the cultural and aesthetic value of art at the forefront, taking issue with the idea that art was an expensive wallpaper that may later be traded for a profit just like stocks and bonds. At play was another commensuration concern — 'is art just like stocks and bonds?'- - as well as the potentially trivializing effect of this commensuration, or even the connection with (immoral) gambling and speculation. $^{12}$

This type of opposition to art investment, which tended to be held by the more romantic and idealistic, roughly corresponds to the hostile worlds framework. This “traditionalist view," as I call it, valorized art collectors and patrons; art investment was seen as "parasitic" (Velthuis, 2005) and damaging to a certain ideal of the art world. While some gallerists were quite pragmatic about the investment characteristics of art, I did find some who were utterly against this, show in the comments of a London gallerist.

We've never sold art for investment. If you want to turn your money into an investment, keep it in the bank! ... I think it's important that you must 
like something, if you're going to live with it on your wall, day and night. People tend to underestimate what an individual gets from art. People think it's like buying the car, the washing machine that's going to make them happy, that's rubbish. It's better to have art. I'd rather have art on the wall. $^{13}$

In this sense, the gallerist has a long-term orientation with the art, but it is a different type of 'investment,' one of time and emotion. At the end of the interview, when I gave him my business card, he quipped, “'Investment logics?' That is to say that there is a logic. You need to redefine what investment actually means, and take it out of purely commercial terms."

At the other end of the spectrum were art investment promoters, who were quite similar to those with the independent spheres view about art and money, and did not see any problem with art as an investment.. For example, according to one investing magazine, art is "just like a normal investment," except that "the only dividend that is earned is through the enjoyment and appreciation of having a piece of art on your wall or in your home" (Bolger, 2006), an idea which could inflame even those with moderate views about art as an investment.

Most people fell somewhere in the middle. Gallerists were often pragmatic, and said they might point their clients toward works they thought were more commercial if they asked about investment value. Although the opinions about art as an investment were less hostile, it could still be seen as problematic. To art professor Elaine King, art investment was "like speculation in hedge funds, in pork bellies... I'm not against markets, but to me, what's the purpose of art if you crunch it down to pork bellies?" The 
problem was that "...the art becomes flat." ${ }^{14}$ Her comment illustrates the problems of homogenization and sameness in artwork, suggesting that quality suffers through attending to market values. Another concern about investment in art came up when I attended the panel session "Is the Killer Art Market Killing Art?" put together by the Art Dealer's Association of America in New York. In the session, and speaking in spring 2008, before the financial crisis hit, panel members worried whether financial value was becoming the primary determinant of artistic value, and welcomed a popping of the art market bubble because it would give space to the "true" collectors. ${ }^{15}$

Artists were also pragmatic about the investment properties of artwork. A painter in New York, who also worked in a gallery, said "[b]ut it is an investment. You have to think of it in both ways in this business... Sometimes people will buy something even if they don't like it, because they see that the value would go up." She thought this last point was strange, because presumably she couldn't imagine having something around that one didn't like, ${ }^{16}$ and this sentiment was echoed many times by collectors, gallerists and artists. Despite recognizing that art could be seen as an investment, when I asked the painter if she thought art investment was problematic, she replied that it was "disheartening as an artist. People collecting are consistent and they do like the art."

This type of mixed view can be seen with other artists, with mild disappointment about people who put the investment value of art foremost, but with an understanding that there are people who fall into this category, as seen in the answers of Henrik, a young London artist.

I think... the first time you see them, you immediately dislike them, because the first time you see them is usually at your degree show, and 
they get taken around by various people, and you notice that when they get taken around, they're the people who will scan a room-not for workbut for red dots. And they do-you know; it sounds like a flippant kind of comment, but it's ... it's an observed occurrence-they will look at another 'stamp' [of value], you know, it's been- when it's been [approved by others]- it's annoying... I guess they don't- I mean, you have the ideal investors, of course, [someone who] is also the art lover. ${ }^{18}$

Small red dots, usually eraser-sized stickers, are often used in gallery shows to indicate that a piece has been sold. Thus we can interpret a young painter with many red dots as someone who is desirable, who has sold out most of their show. Later in the interview, Henrik pointed out that although artists may dislike the art investors, this was part of the nature of the system, and part of the problem is that art investors may not know how to evaluate good vs. 'pretty' artwork.

...I don't think we can dislike them ...oh, I don't really dislike them, they're just too different; it's like disliking [thinking] ... it's like disliking politicians. [Laughs] I mean, I guess everyone wants to dislike them, and kind of does, but I mean, they're necessary. And why not? ...it doesn't hurt us. [Modifying this] It does - it warps the market, it warps things a bit. Things tend towards the - sort of the easy joke at the moment. There's this tendency to make it [the easily recognizable artwork], especially painting... Because then, you know, you look at it and you just can't force it... because it's just kind of very pretty, it's very nice to look at, and you just go, 'Well, this is well painted. Well done.' And then 
another person in a bar will see it and go, 'Well, I can see a person in it, so I like it.' ...It warps things, but in the end, you know, you don't have to [agree]. The investors that you like, [they're] just destined to be around and hopefully you'll find them. But what can you do? [laughing]...

Henrik's comments match those of Professor King and others, who felt that undue attention to monetary value created art that was less interesting. Gallerist Gavin Brown suggested a causal mechanism for how this might happen. "There's a lot of money being spent on stuff that shouldn't be spent," he noted when speaking at the "Killer Art" panel. Brown thought that having too much money and speculation in the art market allowed lower quality work to be sold, work that wouldn't normally sell, and this put lower quality items into the market. ${ }^{19}$

\section{PRAGMATIC VIEWS AND 'GOOD MATCHES'}

When I initially approached my research on art as an investment, I thought that the primary opposition to this practice would be around the hostile worlds, commensuration and commodification concerns discussed above. Because this understanding lacks the rich cultural meanings attributed to artwork from the art world, I thought it would be highly problematic to think about financial investment in artwork. It turns out that a bigger area of concern for these actors was in dealing 'properly' with the relationship between art and money, particularly in how art was allocated amongst potential buyers, because this impacts the monetary value of the work. Instead of opposition to the market, this view comprised a set of ethical and moral guidelines for how to behave in the art market, with the knowledge that improper behavior, such as a customer who tries to quickly resell a piece at auction, could damage reputations and long term price levels. 
This is because in the art market there is a norm that prices can never fall (See Velthuis, 2003, 2005), and customers may interpret price drops as in negative ways (Velthuis, 2004), so there has to be a concern for price maintenance.

Expanding on Zelizer's “good matches” (Zelizer, 2000, 2006) as a framework for mixing together art and money, I would like to suggest that a few matching processes that I observed in the contemporary art market. There was a professional obligation by gallerists to match artwork to the correct buyers, ones who would help to promote the artist and deal honorably with the artwork. Another matching process was to sell artwork in ways that did not harm its monetary value, matching the sales format to the buyer's perceptions. Gallerists and other professions in the market portions of the art world took care with the presentation of art and money even if they did not personally see a conflict. Because they recognized that there are many people hold strong cultural views about the "priceless" value of artwork, to keep these people as customers, they needed to uphold certain normative views on how art was to be bought and sold.

A move away from conventional sales practices helps to prove the continuing importance for conventional sales practices to safely bridge the gap between art and money. In September 2008, Sotheby's held an entire sale dedicated to auctioning off 223 new works by Damien Hirst. This was unusual because first-time sales of artwork are almost never conducted by auction houses, except for benefits and other non-profit purposes (Velthuis, 2005). This was one of the first auctions of its kind in the international art market, and although it was a success in terms of both sales and publicity, it also illustrated the continued role of galleries as a first-time sales venue. This unconventional sale took an enormous amount of preparation and was apparently not to 
be repeated any time soon. When questioned about whether they might undertake another auction of this sort, Hirst's manager Frank Dunphy, said they were delighted with the sale, but "No, nothing is planned. You get one hit of this and you couldn't do it again" (Quoted in Tully, 2008). Moreover, despite the success of this sale, art collectors did not necessarily like the implications. Noted Warhol collector Jose Mugrabi pointed out that "[c]ollectors want to buy for beauty, but this feels like a vulgar way to buy it" (quoted in Crow, 2008).

This example helps to illustrate the way that conventional sales practices provide an acceptable bridge between art and money. Particular sales mechanisms thus provide an "acceptable" way of selling culturally laden objects (Levin, 2007, p. 10), serve to stabilize their value, and may even contribute to the production of belief in the value of art (Velthuis, 2003, p. 184). While it was possible to auction off new artwork, rather than following the convention of first selling artwork in galleries and then later in auction houses, this development was opposed. Selling new artwork in auctions was not a "good match" for many collectors, particularly those with hostile worlds views, suggesting that while innovation is readily in the content of contemporary artwork, rapid changes in the sales practices are less likely, because the current methods represent established, legitimate ways to bring together art and money.

This helps to explain why the traditional practices and structures persist, even when many professionals in the art world do not subscribe to this hostile worlds view themselves. If the hostile worlds view is widespread enough in the wider culture - and particularly, in arts patrons - to make it a social reality, then the practitioners cannot ignore these beliefs, if only because it can harm their profits. It is through this mechanism 
and others, I believe, that the hostile worlds view shapes the way art is bought and sold. By ensuring that the cultural and aesthetic value of art remains distant from the price, art sellers are able to satisfy the many buyers who hold this view.

\section{CONCLUSION}

Unlike researchers who dismiss the hostile worlds view, or the related commensuration and commodification concerns outright, I would like to suggest that it is important to understand the diversity of opinion about what art means and how it is supposed to relate to the market. As I have stressed previously, there are clearly people both within and outside the art world who believe that artistic value can be corrupted by market forces. There are also groups of people who feel this is never the case, including many art investors, as well as those who see that speculative activity can be damaging at times, such as the gallerists. Understanding the continuing prevalence of the hostile worlds view also highlights the importance of existing sales practices and norms in the art market, which deemphasize the relationship between art and money, or bring the two together through long-established, 'acceptable' mechanisms.

The idea of "good matches" (Zelizer, 2000, 2006) is also useful to in thinking about how to coordinate the art market behavior of people who may hold radically different views on the appropriate relationships between art and the market. Artists, gallerists and critics worry about money overpowering meaning, but instead of simple resistance to the market, they recognize that artwork will be bought and sold, and that artwork can be a lucrative investment. Instead of opposing the market, they employed particular strategies to deal with hostile worlds concerns, such as valorizing collectors and diminishing investors. These strategies also impact to the continued economic 
existence of artists and galleries, helping to establish and maintain desired meanings around something which has subjective and socially constructed prices.

This finding directly contradicts the idea that suggests we do not need aesthetic or cultural theories to understand the art market. While some economic anthropologists suggest that "economic behavior in the art market can be understood without reference to aesthetic theory or the transcendent value of art" (Plattner, 2000, p. 130), my ethnographic research indicates that while we may not need aesthetic theory to understand the art market, we do need a cultural theory to think about market practices. Understanding market culture is necessary to explain how the existence of fundamental beliefs and ideologies, like the hostile worlds view, impact art market processes and mechanisms. 


\section{NOTES}

1. This is usually through moral reasons and beliefs about what is being sold. While children and organs are extreme examples, art also has these types of moral contests.

2. Velthuis roots his version of the independent spheres model in the formalist tradition in art history, in which the intrinsic value of the arts and instrumental values of the economy are radically separated, meaning that they do not corrupt one another (2003: 189). It is my own view that this also corresponds to a neoclassical economics perspective.

3. Phone interview with Randall Willette, CEO of Fine Art Wealth Management (London), an art advisory firm. January 2009.

4. The interviews were semi-structured and questions changed with the role of the interviewee and as the project progressed. About half of these interviews were pre-planned, recorded sessions lasting approximately one hour or more. The other interviews were opportunistic, with interviewees approached at prominent international art fairs and other events; only some of these were recorded. The artists and gallerist interviews primarily came from this category.

5. My warm thanks to the librarians of the Sotheby's Institute of Art in London.

6. Written from fieldnotes from the London Art Fair, January 16, 2009.

7. This point about the transcendental nature of art is based on an audience member question at the Art Dealer's Association of America (ADAA) lecture "Is the Killer Art Market Killing Art?” This was held at the Museum of Modern Art, New York March 26, 2008. 
8. This is because of the professionalization and corporatization of MFA programs, museums and galleries, according to art historian Ian Bourland. (Personal Communication, October 23, 2007).

9. Velthuis labels Robert Hughes as one of the main representatives of the hostile worlds contamination model, where art that is overly linked to the market loses value (2003: 188). 10. Phone interview with art professor Elaine A. King, June 2008.

11. This example is based on a comment by Roland Augustine, director of the Luhring Augustine Gallery, at the ADAA lecture "Intimate Histories of Collecting," which was held at the MoMA education center, New York, on May 10, 2008.

12. This also involves the concern of commensuration with money, but I have split it into another category for theoretical clarity.

13. Personal interview with London gallerist, London Art Fair, January 2009. [LAF1].

Note that an ellipse indicates where I cut some text, whereas an ellipse in parentheses indicates a pause, eg. (...).

14. Phone interview, June 3, 2008.

15. "Is the Killer Art Market Killing Art?" Panel Discussion by the Art Dealer's Association of America, held at the Museum of Modern Art, New York March 26, 2008. Panel participants included art dealers, curators and critics. http://www.artdealers.org/events.forum17.html

16. Personal interview with painter / gallery assistant (anonymous), International Fine Art Fair, New York. May 2008. [NYArt1]

17. Personal interview with painter / gallery assistant (anonymous), International Fine Art Fair, New York. May 2008. [NYArt1] 
18. Personal interview with Henrik Potter, painter and manager of the Free Art Fair.

London, Oct. 2008.

19. “Is the Killer Art Market Killing Art?” ibid.

\section{ACKNOWLEDGEMENTS}

This is revised version of the paper presented at the ESA Conference 'Art, Culture and the Public Sphere,' Venice, 2008. I appreciate the many suggestions and revisions suggested by the conference audience, Yuval Millo of the London School of Economics, Edward LynchBell, and my anonymous reviewers. This research was supported by grants from the American Philosophical Society, the University of Chicago Overseas Dissertation Research Fund, and the University of Chicago Nicholson Center for British Studies. 


\section{REFERENCES}

Bolger. (2006, April 17). Is it just art, or is it investment? The Times.

Campbell, R. A. (2008). Art as a Financial Investment. Journal of Alternative Investments, $10(4)$.

Carrier, D. (2003). Commentaries: New York Art, Pittsburgh Art, Art. Journal of Aesthetic Education, 37(3), 99-104.

Chang, M. D. (Writer) (2008). The Mona Lisa Curse. In M. Chang (Producer). U.K.: BBC Documentary, Aired Sept. 21, 2008.

Chong, D. (2005). Stakeholder Relationships in Contemporary Art. In I. Robertson (Ed.), Understanding International Art Markets and Management (pp. 84-102). London: Routledge.

Crow, K. (2008, Sept. 6). The Man Behind Damien Hirst. The Wall Street Journal.

Edwards, M. D. (1991). How Much Is That Painting Worth? An Essay on the Value of Art. Art Education, 44(1), 9-13.

Espeland, W. N. (2002). Commensuration and Cognition. In K. Cerulo (Ed.), Culture in Mind (pp. 63-88). New York: Routledge.

Espeland, W. N., \& Stevens, M. L. (1998). Commensuration as a Social Process. Annual Review of Sociology, 24, 313-343.

Goodwin, J. (2008). Introduction. In J. Goodwin (Ed.), The International Art Markets: The Essential Guide for Collectors and Investors (pp. 1-32). London and Philadelphia: Pastor-Genève and Kogan Page.

Green, C. (2003). Art in France, 1900-1940. New Haven, CT: Yale University Press.

Haden-Guest, A. (2008, March 30, 2008). Art Attack. The Sunday Times Magazine, pp. 2636.

Healy, K. (2006). Last Best Gifts: Altruism and the Market for Human Blood and Organs. Chicago: University of Chicago Press.

Ho, K. (2009). Liquidated: An Ethnography of Wall Street. Durham, NC: Duke University Press.

Hughes, R. (2008, 13 September). Day of the Dead. The Guardian.

Koenigsberg, L. (1989). Art as a Commodity? Aspects of a Current Issue. Archives of the American Art Journal, 29(3/4), 23-35.

Levin, P. (2007). How do Specialists Price Art? Prices as the product of an epistemic community. Paper presented at the American Sociological Association Annual Meeting, Boston, MA.

Marcus, G. (1995). Ethnography in/of the World System: The Emergence of Multi-Sited Ethnography. In Ethnography Through Thick and Thin. Princeton: Princeton University Press.

Odendahl, T., \& Shaw, A. M. (2002). Interviewing Elites. In J. F. Gubrium \& J. A. Holstein (Eds.), Handbook of Interview Research: Context \& Method (pp. 299-316).

Thousand Oaks, CA: Sage. 
Plattner, S. (2000). Profit Markets and Art Markets. In A. Haugerud, M. Stone \& P. Little (Eds.), Commodities and Globalization: Anthropological Perspectives (pp. 113134): Rowman \& Littlefield.

Radin, M. J. (1996). Contested Commodities: The Trouble with Trade in Sex, Children, Body Parts, and Other Things. Cambridge: Harvard University Press.

Robertson, I. (2005). The International Art Market. In I. Robertson (Ed.), Understanding International Art Markets and Management (pp. 13-36). London: Routledge.

Sassen, S. (2001). The Global City: New York, London and Tokyo. Princeton: Princeton University Press.

Shell, M. (1995). Art \& Money. Chicago: University of Chicago Press.

Shore, C., \& Nugent, S. L. (Eds.). (2002). Elite Cultures: Anthropological Perspectives. London: Routledge.

Steiner, C. (2001). Rights of Passage: On the Liminal Identity of Art in the Border Zone. In F. Myers (Ed.), The Empire of Things: Regimes of Value and Material Culture. Santa Fe: School of American Research Press.

Taylor, P. (2000). World Cities and Territorial States Under Conditions of Contemporary Globalization. Political Geography, 19(1), 5-32.

Thornton, S. (2008, May 1, 2008). The recipe for a record price: auction house hype, media frenzy and billionaire buyers. The Art Newspaper.

Tully, J. (2008, Sept. 16, 2008). Hirst Marathon Totals \$200M, Smashing Expectations. ArtInfo. http://www.artinfo.com/news/story/28577/hirst-marathon-totals-200msmashing-expectations/

Velthuis, O. (2003). Symbolic Meanings of Prices: Constructing the Value of Contemporary Art in Amsterdam and New York Galleries. Theory and Society, 32, $181-215$.

Velthuis, O. (2004). An Interpretive Approach to Meanings of Prices. The Review of Austrian Economics, 17(4), 371-386.

Velthuis, O. (2005). Talking Prices: Symbolic Meanings of Prices on the Market for Contemporary Art. Princeton: Princeton University Press.

Watson, P. (1992). From Manet to Manhattan: The Rise of the Modern Art Market. New York: Random House.

Wolff, J. (1981). The Social Production of Art. New York: St. Martin's Press.

Zaloom, C. (2006). Out of the Pits: Traders and Technology from Chicago to London. Chicago: University of Chicago Press.

Zelizer, V. (1985). Pricing the Priceless Child: The Changing Social Value of Children: Princeton University Press.

Zelizer, V. (2000). The Purchase of Intimacy. Law and Social Inquiry, 25(3), 817-848.

Zelizer, V. (2006). Money, Power, and Sex. Yale Journal of Law and Feminism, 18(1), 303-316. 


\section{University Library}

\section{- M M I N E R VA A gateway to Melbourne's research publications}

Minerva Access is the Institutional Repository of The University of Melbourne

Author/s:

Coslor, E

Title:

Hostile Worlds and Questionable Speculation: Recognizing the Plurality of Views About Art and the Market

Date:

2010

Citation:

Coslor, E. (2010). Hostile Worlds and Questionable Speculation: Recognizing the Plurality of Views About Art and the Market. Wood, D (Ed.). Economic Action in Theory and Practice: Anthropological Investigations, (1), 30, pp.209-224. Emerald Group Publishing Limited.

Persistent Link:

http://hdl.handle.net/11343/59437 